\title{
IDENTIFIKASI MISKONSEPSI MENGGUNAKAN TES DIAGNOSTIK THREE- TIER PADA HUKUM NEWTON DAN PENERAPANNYA
}

\author{
Soraya Kamal' ${ }^{1}$, Diah Mulhayayiah ${ }^{1}$ \\ 1. Program Studi Pendidikan Fisika, Jurusan Pendidikan Matematika dan Ilmu \\ Pengetahuan Alam,Fakultas Tarbiyah dan Keguruan Universitas Islam Negeri Syarif \\ Hidayatullah Jakarta, Indonesia \\ Email: diahmyusuf@gmail.com
}

\begin{abstract}
ABSTRAK
Penelitian ini bertujuan untuk mengetahui pengaruh dan peningkatan model Cooperative Learning berbasis Problem Solving terhadap kemampuan pemecahan masalah siswa pada konsep Fluida Dinamis. Penelitian ini dilakukan di kelas XI-A1 dan XI-A2 SMAN 10 Depok. Penelitian ini berlangsung mulai bulan Maret sampai dengan April 2016. Penentuan sampel ini berdasarkan teknik purpossive sampling. Instrumen yang digunakan adalah intrumen tes berupa essay. Data hasil instrumen tes dianalisis secara kuantitatif. Berdasarkan analisis data, diperoleh hasil uji hipotesis dengan menggunakan uji t terhadap data posttest, yaitu nilai sig sebesar 0.014 dan $\alpha$ sebesar 0,05 yang artinya bahwa sign lebih kecil dari nilai alfanya, sehingga H1 diterima. Hal ini menjelaskan bahwa terdapat pengaruh yang signifikan penerapan model cooperative learning berbasis problem solving terhadap kemampuan pemecahan masalah siswa pada konsep fluida dinamis. Selain itu, nilai rata-rata hasil belajar siswa yang menerapkan model cooperative learning berbasis problem solving lebih tinggi dibandingkan nilai ratarata hasil belajar siswa tanpa menggunakan problem solving. Kemampuan pemecahan masalah siswa pada kelas eksperimen di setiap indikator soal mengalami peningkatan, dengan kategori N-Gain tinggi dan sedang.
\end{abstract}

Kata kunci: Model Pembelajaran Kooperatif, Pemecahaman Masalah, Keterampilan Pemecahan Masalah

\begin{abstract}
This research aims to determine the effect of cooperative learning model based on problem solving to ability students problem solving in dynamic fluid concepts. This research was done in class XI-A1 and XI-A2 in SMAN 10 Depok. The research was done in April 2016. The technique of sampling is purpossive sampling. Instrumen were used in this research is test instrument which is essay. Test instrumen data will be analized quantitatively. Based on data analysis, the result obtained that there is an effect of cooperative learning model based on problem solving to ability students problem solving in dynamic fluid concepts. The result of hypothesis testing against posttest data showed that value of sign is 0.014 and value of $\alpha$ is 0,05 . This showed that sign is lower than $\alpha$, so Ha is accepted. Average of student's learning result that uses cooperative learning model based on problem solving is higher than the average of student learning result without problem solving. The result of the experimental class student's learning is superior in each indicator test with the category of $\mathrm{N}$-gain is high and medium.
\end{abstract}

Keywords: : cooperative learning model, problem solving, ability problem solving.

DOI: http://dx.doi.org/10.15575/jtlp.xxx.xxx

Received: xxx ; Accepted: xxx; Published: xxx 


\section{PENDAHULUAN}

Pembelajaran fisika dalam kurikulum 2013 mengharapkan siswa mampu memahami, menerapkan, menganalisis, membuat produk, dan memecahkan masalah fisika dalam kehidupan sehari-hari. Tetapi, dalam pelaksanaannya proses pembelajaran fisika masih mengutamakan penguasaan konsep saja, tanpa mengembangkan kemampuan siswa untuk memecahkan masalah fisika dan penerapannya dalam kehidupan sehari-hari. Pembelajaran fisika yang bersifat abstrak dan banyak rumus masih sulit dipahami. Selain itu, guru cenderung sering menggunakan soal-soal rutin dari pada menggunakan soal-soal variasi yang mengasah siswa untuk menganalisis masalah. Hal ini yang menyebabkan kurangnya kemampuan pemecahan masalah siswa.

Santyasa mengatakan pentingnya pengembangan kemampuan pemecahan masalah dan pemahaman konsep dalam proses pembelajaran memiliki landasan teoritis. Landasan teoretis tersebut sebagai pijakan dalam mengemas pembelajaran adalah sebagai berikut. (Sanjaya, 2009) Tiga wawasan berpikir dalam pembelajaran Fisika: (a) penyajian materi pelajaran tidak diajarkan, (b) untuk menyimpan sesuatu dalam memori tidak dipelajari (c) menghafal bukanlah bukti dari pemahaman siswa. (2) Guru Fisika dianjurkan untuk mengurangi berceritera dalam pembelajaran, tetapi lebih banyak mengajak para peserta didik untuk bereksperimen dan memecahkan masalah. (3) Guru Fisika dianjurkan lebih banyak menyediakan context-rich problem dan mengurangi context-poor problem dalam pembelajaran (Sanjaya, 2009).

Hasil studi kasus yang dilakukan oleh peneliti ketika melakukan studi pendahuluan pada salah satu sekolah di kota Depok terungkap bahwa proses belajar mengajar dikelas cenderung menitikberatkan pada penerapan rumus-rumus fisika melalui analisa matematis, sehingga siswa berusaha menghapal rumus bukan paham penggunaan rumus tersebut.
Kurangnya keterlibatan siswa dalam proses belajar mengajar, sehingga pelajaran fisika dianggap sulit dan membosankan yang berakibat siswa sulit memahami materi fisika dan hasil belajar fisika pun rendah. Kurangnya variasi metode dan model pembelajaran, karena guru terbiasa di kelas menggunakan metode ceramah dengan urutan menjelaskan, memberi contoh, berlatih, bertanya, dan memberi tugas. Rendahnya kemampuan siswa dalam memecahkan masalah, karena kurangnya latihan soal berbasis masalah dan persoalan fisika dalam kehidupan sehari-hari. Ketika pembelajaran fisika, siswa mengeksplorasi pengetahuan hanya melalui buku paket dan LKS.

Penelitian yang mendukung penelitian ini diantaran penelitian Kulsum mengenai penerapan model pembelajaran Cooperative Problem Solving untuk meningkatkan kemampuan pemahaman konsep dan komunikasi ilmiah siswa pada mata pelajaran fisika menemukan bahwa dalam pembelajaran ini dapat meningkatkan kemampuan pemahaman konsep dan komunikasi ilmiah siswa SMA, meskipun hubungan keduanya tidak signifikan (Kulsum, 2014). Selanjutnya, dalam penelitian Dwi Ratnaningdyah tahun 2015, mengenai penerapan model pembelajaran Novick dipadukan dengan strategi Cooperative Problem Solving (CPS) Untuk Meningkatkan Pemahaman Konsep Dan Kemampuan Pemecahan Masalah Siswa SMA bahwa dapat meningkatkan kemampuan pemahaman konsep dan komunikasi ilmiah siswa SMA (Ratnaningdyah, 2015).

Model Cooperative Learning berbasis Problem Solving selalu diberikan masalah untuk didiskusikan oleh siswa. Masalah yang dikaji ini merupakan konsep fisika yang dikaitkan dengan fenomena dalam kehidupan sehari-hari. Salah satu konsep fisika yang banyak dijumpai dalam kehidupan sehari-hari adalah fluida dinamis, sehingga materi Fisika yang digunakan dalam penelitian ini adalah fluida dinamis. Pada kenyataannya siswa sering mengalami kesulitan dalam memahami fenomena-fenomena yang berkaitan dengan fluida dinamis. Hal ini menghambat siswa untuk mengatasi berbagai masalah fluida dinamis dalam kehidupan sehari- 
hari. Agar siswa mampu menyelesaikan setiap permasalahan terkait materi fluida dinamis maka siswa harus memiliki pemahaman konsep yang jelas dan bermakna karena pemahaman siswa sangat erat kaitannya dengan pola berpikir atau bernalar.

Menurut Liliasari, mengatakan belajar sains identik dengan membangun keterampilan berpikir tingkat tinggi yang salah satunya adalah pemecahan masalah. Melalui pengamatan fenomena inilah siswa belajar mengamati, mencari data, menafsirkan, menyimpulkan, dan akhirnya dapat mengaitkan masalah dengan konsep yang berkaitan dengan fenomena. Selanjutnya dengan pemahaman konsep yang dimiliki maka siswa dapat menyelesaikan masalah-masalah dalam kehidupan sehari-hari yang terkait dengan konsep fluida dinamis (Haryani, 2011).

Model pembelajaran Cooperative berbasis Problem Solving merupakan suatu model pembelajaran yang melakukan pemusatan pada pengajaran dan keterampilan pemecahan masalah dalam kelompok-kelompok kecil yang memiliki tingkat kemampuan berbeda. Setiap anggota dalam kelompok saling kerjasama dan membantu untuk memahami suatu bahan permasalahan yang terdiri dari tahap klarifikasi masalah, menampilkan masalah secara fisika, merencanakan strategi pemecahan secara berkelompok, menjalankan rencana, mengkomunikasikan hasil dan mengevaluasi. (Suprijono: 2012) berdasarkan temuan Subratha (2007) menyatakan bahwa penerapan pembelajaran kooperatif dengan pendekatan problem solving dapat meningkatkan pemahaman konseptual fisika dan prestasi belajar siswa. Model pembelajaran Cooperative berbasis Problem Solving telah memberikan kesempatan seluas-luasnya kepada para siswa secara berkelompok/ bekerjasama untuk mengembangkan dan mengintegrasikan suatu permasalahan fisika (Kulsum, 2014)

Model pembelajaran Cooperative berbasis problem solving merupakan model yang dirancang dengan menggunakan LKS berbasis problem solving tipe Polya. Tahapan pembelajaran Cooperative dilaksanakan selama penyampaian materi di kelas berbantukan bahan ajar LKS berbasis problem solving dalam memecahkan soal yang diberikan. Latihan soal yang dikerjakan oleh siswa didiskusikan bersama teman kelompoknya, sehingga semua siswa berpartisipasi dan saling membantu untuk memberi pemahaman materi dan dapat memecahkan permasalahan soal fisika baik secara konsep maupun penerapan dalam kehidupan sehari-hari.

Pemecahan masalah adalah suatu proses mental dan intelektual dalam menemukan suatu masalah dan memecahkannya berdasarkan data dan informasi yang akurat, sehingga dapat diambil kesimpulan yang tepat dan cermat (Hamalik, 2008). Pemecahan atau penyelesaian masalah merupakan proses penerimaan tantangan dan kerja keras untuk menyelesaikan masalah tersebut. Jadi aspek penting dari makna masalah adalah bahwa penyelesaian yang diperoleh tidak dapat dikerjakan dengan prosedur rutin. Lencher menyatakan bahwa memecahkan masalah adalah proses menerapkan pengetahuan yang telah diperoleh sebelumnya ke dalam situasi baru yang belum dikenal (Wardhani, 2010). Menurut Pupuh Fathurrohman, problem solving (pemecahan masalah) adalah belajar memecahkan masalah. Pada tingkat ini anak didik belajar merumuskan dan memecahkan masalah, memberikan respon terhadap rangsangan yang menggambarkan atau membangkitkan situasi problematika yang mempergunakan berbagai kaidah yang telah dikuasainya (Fathurrohman, 2001).

Tujuan penelitian ini adalah untuk mengetahui pengaruh penerapan cooperative learning berbasis problem solving terhadap kemampuan pemecahan masalah siswa pada konsep fluida dinamis

\section{METODE PENELITIAN}


Penelitian ini dilaksanakan pada semester genap tahun ajaran 2015-2016. Penelitian ini dilakukan mulai bulan Maret sampai dengan April 2016 dilaksanakan di sekolah SMA Negeri 10 Depok.

Metode penelitian yang digunakan dalam penelitian ini adalah metode kuasi eksperimen (Quasi-experiment) karena melibatkan penggunaan kelompok subjek utuh yang secara alami sudah terbentuk kemudian memberikan perlakuan eksperimen. Desain penelitian yang digunakan dalam penelitian ini adalah "Nonequivalent Control Group Design" (Sugiyono, 2008)

Penelitian ini dilakukan pada dua kelompok, yaitu kelompok eksperimen dan kelompok kontrol. Sebelum perlakuan diberikan, pretest dilakukan pada kedua kelompok untuk mengetahui pengetahuan awal siswa tentang fluida dinamis. Kemudian perlakuan diberikan pada kelompok eksperimen berupa model cooperative learning berbasis problem solving dalam pembelajaran, sedangkan kelas kontrol melakukan pembelajaran konvensional. Setelah perlakuan diberikan, posttest dilakukan pada kedua kelompok untuk mengetahui kemampuan pemecahan masalah siswa pada konsep fluida dinamis.

Instrumen tes yang digunakan berupa tes subjektif jenis essai sebanyak 10 soal dan disusun berdasarkan indikator yang hendak dicapai. Instrumen ini mencakup ranah kognitif aspek analisis (C4).

Validasi instrumen tes menggunakan program anates. Pengolahan data hasil penelitian untuk mengetahui peningkatan pemecahan masalah dengan menggunakan uji N-Gain dan uji hipotesis dengan menggunakan uji $t$ dengan bantuan prog ram SPSS. Persamaan N-Gain adalah sebagai berikut (Sugiyono, 2008)

$$
\text { N-Gain }=\frac{\text { Skor Posttest }- \text { Skor Pretest }}{\text { Skor Ideal-Skor Pretest }}
$$

\section{HASIL DAN PEMBAHASAN}

Data hasil pretest kemampuan pemecahan masalah siswa merupakan data yang diambil pada kelas eksperimen sebelum pembelajaran dengan menggunakan model cooperative learning berbasis problem solving dan kelas kontrol sebelum pembelajaran dengan menggunakan model konvensional. Berikut ini disajikan tabel deskripsi statistik untuk hasil pretest kelas kelas eksperimen dan control.

Tabel 1. Ukuran Pemusatan dan Penyebaran Data Hasil Pretest Kelas Eksperimen dan Kelas Kontrol

\begin{tabular}{ccc}
\hline $\begin{array}{c}\text { Pemusatan dan } \\
\text { Penyebaran } \\
\text { Data }\end{array}$ & $\begin{array}{c}\text { Kelas } \\
\text { Eksperimen }\end{array}$ & $\begin{array}{c}\text { Kelas } \\
\text { Kontrol }\end{array}$ \\
\hline Banyak data & 30 & 30 \\
\hline Nilai terendah & 7 & 8 \\
\hline Nilai tertinggi & 38 & 40 \\
\hline Median & 22,00 & 22,50 \\
\hline Modus & 21,87 & 23,90 \\
\hline Standar deviasi & 8,45 & 9,02 \\
\hline Rata-rata & 22,30 & 22,37 \\
\hline
\end{tabular}

Data hasil posttest kemampuan pemecahan masalah siswa merupakan data yang diambil pada kelas eksperimen setelah pembelajaran dengan menggunakan model cooperative learning berbasis problem solving dan kelas kontrol setelah pembelajaran dengan menggunakan model konvensional. Berikut ini disajikan tabel deskripsi statistik untuk hasil posttest kelas eksperimen dan kontrol

Tabel 2. Ukuran Pemusatan dan Penyebaran Data Hasil Posttest Kelas Eksperimen dan Kelas Kontrol

$\begin{array}{ccc}\text { Pemusatan dan } & \text { Kelas } & \text { Kelas } \\ \text { Penyebaran Data } & \text { Eksperimen } & \text { Kontrol }\end{array}$

\begin{tabular}{ccc}
\hline Banyak data & 30 & 30 \\
\hline Nilai terendah & 52 & 48 \\
\hline Nilai tertinggi & 89 & 84 \\
\hline Median & 68,42 & 64,60 \\
\hline Modus & 69,50 & 65,00 \\
\hline Standar deviasi & 10,46 & 9,46 \\
\hline Rata-rata & 70,40 & 64,77 \\
\hline
\end{tabular}


Peningkatan kemampuan pemecahan masalah siswa pada kelas eksperimen dan control dapat dilihat berdasarkan tabel berikut:

Tabel 3. Peningkatan Kemampuan Pemecahan Masalah Kelas Eksperimen dan Kelas Kontrol

\begin{tabular}{ccccc}
\hline $\begin{array}{c}\text { Indik } \\
\text { ator }\end{array}$ & $\begin{array}{c}\text { N-Gain } \\
\text { Rata- } \\
\text { rata } \\
\text { Eksp }\end{array}$ & $\begin{array}{c}\text { Kategori } \\
\text { N-Gain }\end{array}$ & $\begin{array}{c}\text { N-Gain } \\
\text { Rata- } \\
\text { rata } \\
\text { Kontrol }\end{array}$ & $\begin{array}{c}\text { Kategor } \\
\text { i N-Gain }\end{array}$ \\
\hline 1 & 0.8 & Tinggi & 0.5 & Sedang \\
\hline 2 & 0.7 & Tinggi & 0.5 & Sedang \\
\hline 3 & 0.6 & Sedang & 0.5 & Sedang \\
\hline 4 & 0.6 & Sedang & 0.5 & Sedang \\
\hline 5 & 0.6 & Sedang & 0.5 & Sedang \\
\hline 6 & 0.5 & Sedang & 0.4 & Sedang \\
\hline $\begin{array}{c}\text { Rata- } \\
\text { rata }\end{array}$ & 0.6 & Sedang & 0.5 & Sedang \\
\hline
\end{tabular}

Indikator 1 sampai dengan 6 merupakan aspek kognitif $\mathrm{C} 4$ yang terdiri dari

1. Menerapkan persamaan kontinuitas, debit fluida, dan daya generator.

2. Menganalisis persamaan kontinuitas, debit fluida, dan daya generator dalam kehidupan sehari-hari.

3. Menerapkan persamaan Bernoulli dan teorema Torricelli dalam kehidupan sehari-hari.

4. Memformulasikan persamaan Bernoulli dan teorema Torricelli dalam kehidupan sehari-hari.

5. Menganalisis persamaan Bernoulli dan teorema Torricelli dalam kehidupan sehari-hari.

6. Menganalisis aplikasi persamaan Bernoulli pada alat penyemprot, karburator, dan gaya angkat pesawat serta alat ukur kelajuan fluida dalam kehidupan sehari-hari.

Hasil uji normalitas sebagai uji prasyarat hipotesis disajikan pada tabel berikut

Tabel 4. Uji Normalitas Kelas Eksperimen dan Kelas Kontrol

\begin{tabular}{|c|c|c|c|c|}
\hline \multirow{2}{*}{$\begin{array}{c}\text { Variab } \\
\text { el }\end{array}$} & \multicolumn{2}{|c|}{ Kelas Eksperimen } & \multicolumn{2}{|c|}{ Kelas Kontrol } \\
\hline & Pretes & Postes & Pretes & Postes \\
\hline
\end{tabular}

\begin{tabular}{ccccc}
\hline $\begin{array}{c}\text { Chi- } \\
\text { Square }\end{array}$ & $4.133^{\mathrm{a}}$ & $6.267^{\mathrm{a}}$ & $5.133^{\mathrm{a}}$ & $4.000^{\mathrm{a}}$ \\
\hline $\mathrm{df}$ & 15 & 15 & 16 & 14 \\
\hline $\begin{array}{c}\text { Asymp. } \\
\text { Sig. }\end{array}$ & .997 & .975 & .995 & .995 \\
\hline$\alpha$ & 0.05 & 0.05 & 0.05 & 0.05 \\
\hline $\begin{array}{c}\text { Kesim- } \\
\text { pulan }\end{array}$ & Normal & Normal & Normal & Normal \\
\hline
\end{tabular}

Hasil uji normalitas berdasarkan table di atas data hasil penelitian bersifat normal karena nilai sig. lebih besar dari 0.05. Hasil uji homogenitas sebagai uji prasyarat kedua hipotesis disajikan pada tabel berikut

Tabel 5. Uji Homogenitas Pretes dan Postes Kelas Eksperimen dan Kelas Kontrol

\begin{tabular}{ccc}
\hline Variabel & Pretes & Postes \\
\hline Lev statistik & .527 & .092 \\
\hline df1 & 1 & 1 \\
\hline df2 & 58 & 58 \\
\hline sig & .471 & .763 \\
\hline$\alpha$ & 0.05 & 0.05 \\
\hline Kesimpulan & Homogen & Homogen \\
\hline
\end{tabular}

Hasil uji homogenitas berdasarkan tabel di atas memperlihatkan bahwa keseluruhan data hasil penelitian bersifat baik pretes maupun postes bersifat homogen

Hasil uji hipotesis disajikan pada tabel berikut

Tabel 6. Uji Hipotesis Pretes dan Postes Kelas Eksperimen dan Kelas Kontrol

\begin{tabular}{ccc}
\hline Variabel & Pretes & Postes \\
\hline Mean Diff & -.100 & 6.700 \\
\hline Std Error & 2.299 & 2.469 \\
\hline sig & .995 & .014 \\
\hline$\alpha$ & 0.05 & 0.05 \\
\hline Kesimpulan & ${\text { Tolak } \mathrm{H}_{1}}$ & Terima $_{1}$ \\
\hline
\end{tabular}

Berdasarkan table di atas pada pretes kesimpulannya adalah tolak $\mathrm{H}_{1}$ artinya tidak terdapat perbedaan kemampuan pemecahan masalah antara kelas eksperimen dengan kelas kontrol, sedangkan pada data postes terima $\mathrm{H}_{1}$ artinya terdapat perbedaan kemampuan pemecahan masalah antara kelas eksperimen dengan kelas kontrol. 
Nilai rata-rata pretest kelas eksperimen sebesar 22,30 sedangkan nilai rata-rata kelas kontrol sebesar 22,37. Perbedaan rata-rata kelas ini tidak terlalu jauh, dikarenakan sebaran kemampuan siswa dikedua kelas tersebut hampir sama. Setelah dilakukan posttest, nilai kemampuan pemecahan masalah kelas eksperimen maupun kelas kontrol sama-sama mengalami peningkatan. Namun nilai rata-rata kelas eksperimen mangalami peningkatan yang lebih signifikan dibandingkan dengan nilai ratarata kelas kontrol. Peningkatan yang signifikan tersebut dapat dilihat dari nilai rata-rata (mean) siswa kelas eksperimen yang menggunakan model cooperative learning berbasis problem solving lebih tinggi dibandingkan dengan siswa kelas kontrol yang menggunakan model konvensional. Kelas eksperimen memperoleh nilai rata-rata sebesar 70,40 sedangkan kelas kontrol memperoleh nilai 64,77. Keadaan ini menunjukkan bahwa kemampuan pemecahan masalah siswa pada pembelajaran konsep fluida dinamis dengan menggunakan model cooperative learning berbasis problem solving lebih baik dibandingkan dengan model konvensional.

Pembelajaran dengan menggunakan model cooperative learning berbasis problem solving menjadikan siswa secara aktif ikut serta dalam kegiatan belajar, karena setiap kelompok berisikan anggota dengan tingkat kecerdasan yang berbeda dan setiap anggota berusaha untuk memecahkan masalah yang diberikan dan berusaha memahami masalah, merencanakan solusi dari masalah tersebut serta mencoba memecahan masalah dengan melaksanakan rencana solusi yang telah dibahas secara bersama dengan anggota kelompoknya masing-masing. Setelah mencapai solusi kelompok pun melakukan evaluasi atas solusi yang didapat dengan mempresentasikan hasilnya didepan kelas. Selain itu setiap anggota mengisi lembar kerja dan menuliskan hasil dari solusi yang didapat dari hasil kelompoknnya secara individu. Dengan demikian kemampuan pemecahan masalah siswa semakin dilatih dan terjadi peningkatan yang cukup signifikan.
Peningkatan yang signifikan tersebut juga berbanding lurus dengan hasil uji hipotesis yang menunjukkan bahwa terdapat pengaruh yang signifikan dalam penggunaan model cooperative learning berbasis problem solving terhadap kemampuan pemecahan masalah siswa pada konsep fluida dinamis. Hal tersebut didukung oleh hasil uji hipotesis nilai posttest, dimana nilai $t_{\text {hitung }}$ lebih besar dibandingkan nilai $t_{\text {tabel }}$ yaitu $3,679>2,00$. Karena nilai $t_{\text {hitung }}>t_{\text {tabel }}$ maka dapat disimpulkan bahwa $\mathrm{H}_{1}$ diterima dan $\mathrm{H}_{0}$ ditolak, artinya terdapat pengaruh penggunaan model cooperative learning berbasis problem solving dalam konsep fluida dinamis terhadap kemampuan pemecahan masalah siswa.

Penggunaan model cooperative learning berbasis problem solving dapat meningkatkan kemampuan pemecahan masalah siswa. Hal ini dikarenakan dalam model cooperative learning siswa dikelompokkan dan berdiskusi dalam upaya memecahkan masalah fisika yang diberikan oleh guru dalam proses pembelajaran. Usaha yang dilakukan guru untuk meningkatkan kemampuan pemecahan masalah siswa adalah mengusahakan pemberian soal-soal yang berisi kemampuan pemecahan masalah dengan menggunakan bahasa yang mudah dimengerti siswa dan isinya pun selalu disesuaikan dengan materi yang dipelajari.

Kemampuan siswa dalam memecahkan masalah memang harus selalu ditingkatkan. Karena kemampuan ini sangat penting dalam kehidupan sehari-hari, setiap manusia selalu berhadapan dengan masalah yang harus diselesaikan, termasuk masalah matematis atau masalah yang solusinya perlu perhitungan matematik. Melalui pembelajaran dengan pemecahan masalah siswa dilatih untuk menggunakan kemampuan berpikir kritis dalam setiap tahapan pemecahan masalah mulai dari memahami masalah, merencanakan pemecahan, melaksanakan rencana pemecahan sampai pada mengevaluasi kembali pemecahan yang telah dilaksanakan. Dengan selalu dilatih untuk menggunakan kemampuan berpikir kritis dalam pembelajaran dengan pemecahan masalah dapat 
menumbuh kembangkan kemampuan memecahkan masalah.

\section{KESIMPULAN}

Berdasarkan data hasil penelitian dan pembahasan, maka dapat disimpulkan bahwa terdapat pengaruh yang signifikan dalam penggunaan model cooperative learning berbasis problem solving terhadap kemampuan pemecahan masalah siswa pada konsep fluida dinamis. Peningkatan kemampuan pemecahan masalah siswa juga berada pada kategori sedang. Nilai rata-rata kemampuan pemecahan masalah siswa kelas eksperimen lebih tinggi dibandingkan siswa kelas kontrol. Dengan demikian pembelajaran menggunakan model cooperative learning berbasis problem solving terbukti lebih unggul dalam meningkatkan kemampuan pemecahan masalah pada kelas eksperimen.

Pengembangan ke depan saran yang dapat diberikan adalah dalam melakukan penelitian model cooperative learning selanjutnya disarankan menggunakan tipe lain guna meningkatkan kemampuan pemecahan masalah siswa.

\section{UCAPAN TERIMAKASIH}

Penulis mengucapkan terima kasih kepada Guru dan Kepala Sekolah SMAN 10 Depok yang telah mengijinkan penulis untuk melakukan penelitian di sekolah

\section{DAFTAR PUSTAKA}

Desti Haryani. 2011. Pembelajaran Dengan Pemecahan Masalah Untuk Menumbuhkembangkan Kemampuan Berpikir Kritis Siswa, Prosiding Seminar Nasional Penelitian, Pendidikan dan Penerapan MIPA, Fakultas MIPA, Universitas Negri Yogyakarta : 121

Fathurrohman, Pupuh. 2001, Strategi Belajar Mengajar Suatu Pendekatan Baru dan Praktik. Bandung: Insan Mandiri
Hamalik, Oemar. 2008. Kurikulum dan Pembelajaran, Jakarta: Bumi Aksara

Kulsum, U., 2014. Penerapan Model Pembelajaran Cooperative Problem Solving untuk Meningkatkan Kemampuan Pemahaman Konsep dan Komunikasi Ilmiah Siswa pada Mata Pelajaran Fisika. Unnes Physics Educational Journal, : 74

Ratnaningdyah, Dwi. 2015 Penerapan model pembelajaran Novick dipadukan dengan strategi Cooperative Problem Solving (CPS) Untuk Meningkatkan Pemahaman Konsep Dan Kemampuan Pemecahan Masalah Siswa SMA. Prosiding Seminar Nasional Penelitian, Pendidikan dan Penerapan MIPA, Fakultas MIPA, Universitas Negri Yogyakarta : 33.

Sanjaya, Wina. 2009. Strategi Pembelajaran Berorientasi Standar Proses Pendidikan. Jakarta: Kencana Prenada Media Group.

Sugiyono. 2008. Metode Penelitian Pendidikan. Bandung: Alfabeta

Wardhani, S., Pramono. S.S., dan Endah Wahyuningsih. 2010. Pembelajaran Kemampuan Pemecahan Masalah Matematika di SD. Yogyakarta: Pusat Pengembangan dan Pemberdayaan Pendidik dan Tenaga Kependidikan Matematika 